\title{
NEW SPACE (NOWA ERA DZIAŁALNOŚCI W KOSMOSIE) - PROBLEMY PRAWNE I GOSPODARCZE ORAZ KWESTIE BEZPIECZEŃSTWA
}

\section{WPROWADZENIE}

Już od wczesnych lata 80 . XX wieku w niektórych państwach zachodnich, głównie w USA, nastąpił znaczny wzrost udziału sektora prywatnego w działalności kosmicznej. Korzyści komercyjne z niej płynące już teraz można zaliczyć do największych w działalności podmiotów gospodarczych na świecie ${ }^{1}$. W tej sytuacji zaistniała konieczność przyjrzenia się przepisom międzynarodowego prawa kosmicznego, gdyż z uwagi na rosnące zaangażowania kapitału prywatnego i rozwoju technologii istnieje potrzeba wyjaśnień wielu kwestii, na przykład różnic w interpretacji pojęć use $e^{2}$ i exploration,

Dr hab. MaŁgorzata PolKowsKA - Kierownik Katedry Prawa Międzynarodowego Instytutu Prawa, Akademia Sztuki Wojennej, al. Gen. A. Chruściela 103, 00-910 Warszawa, e-mail: m.polkowska@akademia.mil.pl; ORCID: https://orcid.org/0000-0002-6633-2222

Kierownik projektu naukowego MON „Wyzwania polityki bezpieczeństwa kosmicznego na świecie a narodowy i europejski system SSA w kontekście ewolucji środowiska kosmicznego". Niniejsza publikacja powstała w wyniku realizacji projektu o numerze $66 \mathrm{w}$ ramach Programu Grantów Badawczych Ministerstwa Obrony Narodowej RP.

${ }^{1}$ D. SAgar, Privatization of the intergovernmental satellite organizations, [w:] Le droit de l'éspace et la privatisation des activités spatiales, red. Armel Kerrest, Paris: Journée d'étude 2003, s. 43-61.

${ }^{2}$ K. NymAn-MetCalf, Activities in space- appropriation or use? Göteborg: Uppsala Universitet, Acta Universitatis Upsaliensis, 1999, s. 192-194. W istniejącym prawie kosmicznym, w traktatach i prawie zwyczajowym, zasada niezawłaszczania i wolności wykorzystania są ściśle umocowane. Analiza tych zasad pokazuje, że w niektórych przypadkach mogą być one sprzeczne. Możliwy konflikt pomiędzy wykorzystaniem i zawłaszczeniem jest wyzwaniem dla nowego prawa kosmicznego. Nie ma w prawie kosmicznym definicji słowa use. Kilka wskazówek daje Traktat o Księżycu, ale nie był on przyjęty przez większość państw. Niektóre zasady zawiera układ kosmiczny z 1967 r. Najważniejsza wskazówka to ta, że wykorzystanie zasobów Kosmosu, w tym ciał niebieskich, jest dozwolone (np. zabranie zasobu). 
związanych z przestrzenią kosmiczną ${ }^{3}$. Wobec braku przepisów międzynarodowych niektóre państwa regulują kwestie związane z działalnością podmiotów prywatnych poprzez wewnętrzną legislację ${ }^{4}$. Dzięki temu powstała idea globalnego współdziałania państwa i podmiotów prywatnych ${ }^{5}$. Dobrym przykładem są tu przepisy regulujące działalność Międzynarodowej Stacji Kosmicznej (ISS) ${ }^{6}$. Nadal jednak brakuje wystarczających rozwiązań prawnych regulujących np. operacje satelitów. Ułatwienia w wynoszeniu satelitów powinny być normami międzynarodowymi, niezależnymi od uwarunkowań politycznych i równe dla wszystkich, także dla podmiotów prywatnych ${ }^{7}$.

Przy prowadzeniu turystyki kosmicznej przez wahadłowce (RLV) należy zapewnić bezpieczny powrót załodze, pasażerom i ładunkom. System musi być sprawny i sprawdzony pod kątem jakości; z drugiej strony, musi przynosić określone korzyści ekonomiczne. Do prowadzenia takiego biznesu potrzebne są jednak liczne procedury związane w szczególności z przewozem (wyposażenie statku, rodzaje tras, ubezpieczenie załogi i pasażerów, procedury awaryjne, infrastruktura portów kosmicznych itp. $)^{8}$.

Komercjalizacja działalności kosmicznych jest naturalnym rezultatem ciągłego rozwoju technologii kosmicznej. Powoduje ona jednak powstanie licznych problemów prawnych w związku z odpowiedzialnością cywilną. Niektórzy uważają, że kwestię tej odpowiedzialności należy pozostawić samemu rynkowi ${ }^{9}$. Usługi transportu kosmicznego oraz telekomunikacja mogą

${ }^{3}$ K.-H. BöcKSTIEGEL, Introductory remarks, [w:] Research and Invention in outer space. Liability and Intellectual Property Rights, red. S. Mosteshar, Dodrecht: Martinus. Nijhoff Publishers 1995, s. 1-6.

${ }^{4}$ R. SKAAR, Commercialization of space and its evolution, will new ways to share risks and benefits open up a much largare space market, European Space Policy Institute. Report nr 4, maj 2004, s. 5 n.

5 J. Monserrat Filho, Why and how to define ,global public interest”, Proceeding of the forty third colloquium on the law of outer space, International Institute of Space Law of the International Astronautical Federation, 2-6 X 2000, Brazil-UN (United Nations): Rio de JaneiroNew York, s. 22-32.

${ }^{6}$ A. FARAND, Commercialization of International Space Station Utilization: The European partner's Viewpoint, ,Air and Space Law” (ASL) 28 (2003), nr 2, s. 83-88.

${ }^{7}$ V. LEISTER, M.C. FRAZIER, The role of national and international law in the regulation of space activities, Proceeding of the forty third colloquium on the law of outer space, International Institute of Space Law of the International Astronautical Federation, 2-6 X 2000, Brazil-UN (United Nations): Rio de Janeiro-New York, s. 164-167.

${ }^{8}$ W.A. Gaubatz, Comments on Certification Standards for New Reusable Launch Vehicles, http://www.spacefuture.com/archive/comments_on_certification_standards_for_new_reusable_ve hicles.shtml (dostęp: 12.08.2020).

9 P.D. BostwICK, Liability of aerospace manufacturers: MacPherson v. Buick Sputters into the space age, „Journal of Space Law” (JSL) 22 (1994), nr 1 i 2, s. 75-96. Autor zwraca uwagę na 
wymagać oddzielnych i specyficznych przepisów międzynarodowych. Inni autorzy uważają, że lot kosmiczny może być traktowany z wykorzystaniem czwartej i trzeciej wolności lotniczej (łącznie), charakterystycznej dla lotnictwa cywilnego. Transport satelity na Ziemię może być porównany do kabotażu (satelita uznawany jest za quasi-terytorium państwa) ${ }^{10}$.

Obecnie w niektórych państwach prywatne przedsiębiorstwa muszą tylko uzyskać od państwa rejestracji zezwolenie na prowadzenie swojej działalności. Z prawnego punktu widzenia techniczny i operacyjny dostęp do Kosmosu jest także wolny. Odpowiednia notyfikacja wynoszonego urządzenia poza Ziemię jest wymagana dla zapewnienia bezpieczeństwa ${ }^{11}$. Nie wszyscy prawnicy są jednak zwolennikami nadmiernej liberalizacji w Kosmosie ${ }^{12}$; wedle nich „międzynarodowy regulator” powinien wziąć pod uwagę różnice opinii i wymagań państw, stąd prawa transportowe i rozszerzenie działalności kosmicznej nie mogą być dla wszystkich państw takie same ${ }^{13}$. Niektórzy autorzy zwracają uwagę na potrzebę stworzenia nowej gałęzi prawa kosmicznego, to jest prawa zajmującego się działalnością komercyjną w Kosmosie ${ }^{14}$.

Jeszcze w latach 80. XX wieku Stany Zjednoczone ogłosiły program komercjalizacji technologii kosmicznej, w którym znalazły się m.in. zapewnienia dogodnych warunków dla rozwoju prywatnych firm, kontynuacji poszukiwań i odkryć, ograniczenie ryzyka i restrykcji nakładanych na technologie kosmiczne. Wielu badaczy amerykańskich sądzi, że przedsiębiorstwom z USA prowadzącym działalność kosmiczną należy zezwolić na obchodzenie niektórych przepisów do czasu, aż one same stworzą odpowiednie przepisy dotyczące operacji kosmicznych ${ }^{15}$.

rosnącą liczbę spraw sądowych związanych z błędem producenta urządzeń kosmicznych.

${ }^{10}$ L. RAVILlon, Droits des contrasts spatiaux: quelques thèmes récurrents, „Revue Française de Droit Aérien et Spatial" (RFDAS) 1998, s. 61-62. Autor mówi o ewolucji zawieranych umów kosmicznych z uwagi na rozwijającą się technologię.

${ }^{11} \mathrm{H}$. WASSENBERGH, The art of regulating international air and space transportation, an exercise in regulatory approaches to analyzing air and space transportation, „Annals of Air and Space Law" (AASL) 23 (1998), s. 201-229.

${ }^{12}$ A. KERREST, Launching spacecrafts from the sea and the Outer Space Treaty: The Sea Launch Project, „Air and Space Law” 1998, nr 1, s. 16-21.

${ }^{13}$ H. WASSENBERGH, Access of private entities to airspace and outer space, AASL 24 (1999), s. 311-331.

${ }^{14}$ P.A. SALIN, Orbites, fréquences et asteroïdes à l'heure de la commercialization des activités spatiales (vers une appropriation graduelle du patrimoine de l'éspace?), AASL 26 (2001), s. 179-195.

${ }^{15}$ P.S. DEMPSEY, The evolution of U.S. Space Policy, AASL 33 (2008), s. s. 325-343; S. TREPCZYNSKI, Benefits of Granting Immunity to Private Companies Involved in Commercial Space Ventures, AASL 31 (2006), s. 403. 
Prawo międzynarodowe nie przeciwstawia się prowadzeniu działalności przez podmioty prywatne. Obowiązki nałożone w art. VI układu kosmicznego $(\mathrm{OST})$ z 1967 r., dotyczące autoryzacji i stałego nadzoru, są w gestii państw. Kwestia związana z jurysdykcją staje się dotkliwa dla podmiotów prywatnych, kiedy ta wolność zostaje transponowana na poziom narodowy i prywatny. Koncepcja odpowiedzialności (ang. responsibility) za działalność niezgodną z zasadami prawa międzynarodowego, w tym działalność podmiotów prywatnych, i odpowiedzialność państwa za szkody wyrządzone przez obiekty kosmiczne, w tym przez prywatnych operatorów, staje się najbardziej fundamentalną kwestią międzynarodowego prawa kosmicznego z perspektywy prywatyzacji działalności kosmicznej.

Państwa są więc zmuszane do podjęcia wewnętrznych działań, do monitorowania i kontroli działalności prywatnej przedsiębiorców. Współdziałanie międzynarodowej i krajowej legislacji jest konieczne w obliczu prywatyzacji działalności kosmicznej. Państwa kontrolują prywatne przedsiębiorstwa; mają mechanizmy legislacyjne potrzebne do ustalenia reżimu licencjonowania i monitoringu oraz system sankcji. Wydaje się, że prawu międzynarodowemu powinno być pozostawione zdefiniowanie parametrów i zakresu, w ramach którego taka kontrola prywatnych przedsiębiorstw powinna mieć miejsce. Państwa powinny mieć możliwość zadecydowania, w jakich kategoriach winna być prowadzona działalność prywatnych podmiotów na poziomie międzynarodowym ${ }^{16}$.

Konkurencja na rynku działalności kosmicznej pozostaje także poza kompetencją Unii Europejskiej. Decyduje tu więc jurysdykcja krajowa, która przyczynia się do ułatwienia międzynarodowej współpracy w prywatnym sektorze usług komunikacji satelitarnej. Wiele państw wprowadziło przepisy sprzyjające komercjalizacji w swoim prawie krajowym. Są wśród nich państwa unijne oraz trzecie (na przykład Australia, która w ustawie z 1998 r. zapewniła ochronę działalności kosmicznego sektora prywatnego ${ }^{17}$, czy USA, które w ustawie z 1984 r., zmienionej w 1988 r. $^{18}$, wprowadziły pewne upraw-

${ }^{16}$ F.G. VON DER DunK, „Public Space Law and Private Enterprise - The Fitness of International Space Law Instruments for Private Space Activities", [w:] Legal Framework for Privatising Space Activities, Proceedings of the Project 2001 Workshop on Legal Issues of Privatising Space Activities (1999), s. 12-39.

${ }^{17}$ R.J. LeE, The Australian Space Activities Act 1998: building the regulatory capacity for a launch Industry [w:] Proceedings United Nations/International Institute of Air and Space Law Workshop on Capacity Building In Space Law Space Activities (2003), s. 115.

${ }^{18}$ V.J. VISSEPÓ, Legal aspects of reusable launch vehicles, JSL 31 (2005), s. 165-217; Ch.W. STOTLE, International and U.S. national laws affecting commercial space tourism: how 
nienia dla sektora prywatnego ${ }^{19}$ ). W procesie komercjalizacji oprócz zapewnienia bezpieczeństwa oraz wszelkich operacyjnych procedur liczy się czynnik ekonomiczny (tj. rentowność). Podobnie ważne jest, aby odpowiedni organ państwowy został upoważniony do wystawiania komercyjnych licencji dla portów kosmicznych (ang. spaceports ${ }^{20}$ ) i komercyjnych licencji operacyjnych opartych na ocenie zdolności operatorów do zapewnienia publicznego bezpieczeństwa i ochrony własności i środowiska. Termin spaceport nie został zdefiniowany przez międzynarodowe prawo ani przez prawo krajowe USA. W słowniku oksfordzkim termin ten oznacza miejsce, z którego dokonuje się wystrzeleń statków kosmicznych, miejsca startu i lądowania. Każdy spaceport musi być właściwie wyposażony i mieć odpowiednie ułatwienia. Działalność każdego musi być ubezpieczona. W USA mogą one być własnością albo rządu, albo podmiotów prywatnych. Początkowo były używane jedynie do celów wojskowych, z czasem, w erze telekomunikacyjnej, znalazły się także w rękach prywatnych. Kiedy rządowe porty kosmiczne podejmują działalność komercyjną, muszą spełniać wymogi odnośnie do rejestracji i licencjonowania, tak jak komercyjne porty kosmiczne (rządowe wykonujące funkcje dla rządu nie podlegają tym przepisom). Porty kosmiczne mogą być zaklasyfikowane jako naziemne i nieulokowane na Ziemi. W większości przepisy pięciu traktatów kosmicznych dotyczą portów kosmicznych.

\section{NEW SPACE (NOWA ERA W DZIAŁALNOŚCI W KOSMOSIE) I JEJ WYKORZYSTANIE}

Rozwój działalności komercyjnej w Kosmosie spowodował pojawienie się nowego terminu - new space. Termin ten jest powszechnie stosowany przez osoby zaangażowane $\mathrm{w}$ budowę statków kosmicznych, jak również w tworzenie prawa kosmicznego. Termin ten może oznaczać ewolucyjny proces od ery komercjalizacji i prywatyzacji, którą charakteryzowały kontrakty rządowe (gdzie rząd działał jako najemca i nabywca sprzętu) do ery komercyjnej, gdzie rząd i firmy prywatne nabywają usługi z sektora prywatnego. Termin ten jest ściśle związany z rozwojem niszowych obszarów

ITAR tips the balance struck between international law and the CSLAA (Commercial Space Launch Amendment Act), JSL 33 (2007), nr 1, s. 268.

${ }^{19}$ S. TREPCZYNSKI, The benefits of granting immunity, s. 381-404.

${ }^{20}$ M.C. MineIro, Law and Regulation Governing U.S. Commercial Spaceports: Licensing, Liability, and Legal Challenges, „Journal of Air Law and Commerce” 73 (2008), nr 4, s. 759. 
działalności kosmicznej. Jest to nowy model biznesu i nowy rodzaj partnerstwa. Można powiedzieć, że w obecnym świecie wszechobejmującej cyberprzestrzeni człowiek coraz rzadziej liczy na siebie i swoją przyszłość, a jego wiedza opiera się na technologii ${ }^{21}$. Terminu tego używa się także w nowych technologiach, przedsiębiorczości, indywidualnym dostępie człowieka do przestrzeni kosmicznej (np. w osiedlaniu się w Kosmosie) lub w wykorzystywaniu zasobów kosmicznych. Według J. Peltona nowa era działalności w Kosmosie to coś więcej niż tylko nowa działalność komercyjna w przestrzeni kosmicznej ${ }^{22}$.

New space jest domeną dla zupełnie nowych firm (Nanoracks, Skybox i Made In Space), nowych ze starszym kapitałem (Bigelow Aerospace, Blue Origin, SpaceX, Virgin Galactic), starszych firm korzystających z nowych technologii (Orbital Sciences, Boeing, Lockheed Martin). Ponadto, istnieją sojusze pomiędzy nowszymi i starszymi graczami rynkowymi, takimi jak Stratolaunch \& Blue Origin's we współpracy z United Launch Alliance lub przedsiębiorcami, którzy nie zajmują się na co dzień przestrzenią kosmiczną, New space dostrzega nowe problemy prawne i tworzy nowe rozwiązania, dlatego pewność prawna jest tu priorytetem ${ }^{23}$.

Jak już wspomniano, chociaż działalność kosmiczna prowadzona przez podmioty prywatne, na podstawie art. VI OST z $1967 \mathrm{r}^{24}$, jest prawnie możliwa (odpowiedzialność ponosi państwo), nie każda działalność jest już regulowana przez prawo krajowe. Nawet w Stanach Zjednoczonych nie wiadomo, który organ jest odpowiedzialny za wydawanie odpowiednich zezwoleń

\footnotetext{
${ }^{21}$ G.S. RoBINSON, Space jurisdiction and the need for a trans global cybernation: the underlying biological dictates of Humankind dispersal, migration and settlement in near and deep space, AASL 31 (2014), s. 325.

${ }^{22} \mathrm{R}$. JAKHU, Introduction into the conference 3rd Manfred Lachs International Conference on New Space commercialization and the law, 16-17 March 2015, Montreal, ICAO.

${ }^{23}$ Tamże.

${ }^{24}$ Treaty on Principles Governing the Activities of States in the Exploration and Use of Outer Space, including the Moon and Other Celestial Bodies (Outer Space Treaty) 1967; www.unoosa.org (dostęp: 22.11.2019).
} 
na działania niektórych „firm kosmicznych”, a który za nadzór nad nimi ${ }^{25}$. Nowa era wymaga zatem jeszcze lepszych uregulowań prawnych i wypełnienia istniejących luk prawnych, ułatwiając $\mathrm{w}$ ten sposób przedsiębiorcom działanie w Kosmosie.

Stosunkowo najlepsza sytuacja pod tym względem wytworzyła się w telekomunikacji. Niektóre kraje zamierzają zbudować konstelacje składające się z wielu satelitów. Coraz większą rolę odgrywają małe satelity; według obliczeń międzynarodowej firmy konsultingowej Euroconsult, w ciągu najbliższych 5 lat planowane jest wystrzelenie około 500 małych satelitów o wartości około 7,4 mld dolarów. Mini-satelity mają wagę poniżej $1000 \mathrm{~kg}$, mikro - poniżej $100 \mathrm{~kg}$, nano - $10 \mathrm{~kg}$ i pico - $1 \mathrm{~kg}$. Istnieją również Rockwell automation satellites oraz satelity zwane cube sats w kształcie kostek o parametrach 10x10x10x10 cm i wadze od 10 do 100 gramów.

Satelity te znajdują się głównie na niższych orbitach, zazwyczaj bez paliwa. Mają one jednak różne zastosowania i struktury, są mniej lub bardziej skomplikowane, mają różne częstotliwości radiowe i wykorzystują różne rodzaje technologii częstotliwości. Wykorzystywane są przez szereg podmiotów (firmy prywatne, rządy i ich agencje, siły zbrojne, uniwersytety, ośrodki badawcze, a nawet osoby prywatne). Małe satelity są stosowane zarówno w krajach bogatych, jak i rozwijających się. Mogą być one wystrzeliwane przez duże rakiety lub przez małe urządzenia z powierzchni ziemi, morza, powietrza lub przestrzeni kosmicznej ${ }^{26}$. Małe satelity oferują wiele możliwości wykorzystania przestrzeni kosmicznej do celów naukowych, strategicznych i rewolucyjnych. $75 \%$ z planowanych 500 małych satelitów zostanie wykorzystane przez rządy oraz agencje cywilne i obronne.

Małe satelity są głównym narzędziem rozwoju komercjalizacji nowej ery. Są one jednocześnie wyzwaniem dla istniejących traktatów i przepisów. W związku z tym pojawia się pytanie o potrzebę zmiany istniejących przepisów traktatu OST (np. art. VI dotyczący zezwoleń i nadzoru w ramach testów operacyjnych lub art. VIII testów operacyjnych dotyczący rejestracji lub odpowiedzialności międzynarodowej). Pojawiają się pytania dotyczące odpadów kosmicznych, adekwatności częstotliwości radiowych i ich zgodności z systemami bezpieczeństwa. Niektórzy autorzy są zdania, że do bez-

\footnotetext{
${ }^{25}$ M. MinEIRO, Regulatory uncertainty for non-traditional commercial space activities $3^{\text {rd }}$ Manfred Lachs International Conference on New Space commercialization and the law, 16-17 March 2015, Montreal, ICAO.

${ }^{26}$ A. CAZEnAve, Monitoring Sea Level Change from Space, „Space Research Today”, nr 205, sierpień 2019, s. 49.
} 
piecznego prowadzenia prywatnej działalności gospodarczej potrzebne są nowe regulacje dotyczące przestrzeni kosmicznej, ale nie tzw. miękkie prawo, ponieważ nie jest ono wystarczająco silne. Podkreśla się wagę współpracy państw $\mathrm{w}$ takich dziedzinach, jak zarządzanie ruchem kosmicznym ${ }^{27}$ lub ochrona środowiska.

Obecnie charakterystyczną cechą wielkich projektów kosmicznych jest nie tylko praca wielu osób, ale także długi czas ich realizacji. W ESA takim projektem jest np. Rosetta Mission; w roku 2004 wysłano sondę kosmiczną, której celem było prowadzenie badań mających na celu poznanie pochodzenia komet, związków między materią komet a materią międzygwiezdną oraz ich znaczenia dla tworzenia Układu Słonecznego.

Kolejnym projektem europejskim jest program GALLILEO lub Copernicus (program monitoringu Ziemi). Copernicus w świecie coraz bardziej narażonym na klęski żywiołowe i inne katastrofy ma monitorować stan środowiska na lądzie, na morzu i w powietrzu, a tym samym zwiększać bezpieczeństwo obywateli. Ponadto Copernicus jest siłą napędową wzrostu zatrudnienia, ponieważ oferuje możliwość stworzenia do 85000 nowych miejsc pracy.

W pracach Europejskiego Centrum Badań Jądrowych CERN (Conseil Européen pour la Recherche Nucléaire) zaangażowanych jest 2,5 tys. osób z 20 krajów. Jednym z dzieł CERN-u jest m.in. Large Hadron Collider największy na świecie akcelerator. Inne projekty kosmiczne obejmują: ESO (Europejskie Obserwatorium Południowe) z udziałem 16 krajów, 4 ośrodki w Chile (z dobrymi warunkami obserwacyjnymi). W projekcie wykorzystano olbrzymie teleskopy. Historie sukcesów EON to m.in. badanie Drogi Mlecznej i czarnych dziur w Kosmosie. Także amerykańska misja Apollo (której pierwotnym celem było wyprzedzenie ZSRR w wykorzystaniu przestrzeni kosmicznej) stała się wielkim osiągnięciem ludzkości i pobudziła wiele dyscyplin technologicznych. Tak więc projekty kosmiczne są wprawdzie drogie i angażują wiele osób, ale zazwyczaj przynoszą więcej niż się spodziewano, a niekiedy zmieniają nasze pojęcie o wszechświecie ${ }^{28}$.

${ }^{27}$ K. UwE SCHRÖGL, Regulations for future space traffic control and management, [w:] red. J. Pelton and R.S. Jakhu, Introduction to space safety regulations and standards, Nidjihof: Elsevier 2010, s. 303-308.

${ }^{28}$ M. BANASZKIEWICZ, Space projects - conference 28-29 May 2015, Warsaw, seminar by European Centre for Parliamentary Research and Documentation, Economic and Budgetary Affairs some crucial issues for Parliaments in Europe: fiscal policy towards boosting accountability, social security and technological progress. 


\section{MAŁE SATELITY}

Jak już wspomniano, w ostatnich latach wzrosło zainteresowanie małymi satelitami. Odgrywają one ważną rolę, szczególnie w zakresie obserwacji Ziemi i teledetekcji ${ }^{29}$. Dane $\mathrm{z}$ tych obserwacji są wykorzystywane zarówno do celów bezpieczeństwa, humanitarnych, rolniczych, poszukiwawczo-ratowniczych, jak i systemów komunikacji. Mogą być one także traktowane, jako dowody sądowe. Tak np. w Nigerii wprowadzono nowe prawo umożliwiające uznanie danych satelitarnych za dowody w sprawie ${ }^{30}$. Po raz pierwszy we wrześniu 2011 r. dane satelitarne zostały wykorzystane przez Międzynarodowy Trybunał Prawa Morza (ITLOS) do wyznaczenia granicy między Bangladeszem a Birmą w Zatoce Bengalskiej ${ }^{31}$. Nowe zastosowania małych satelitów omawiała ITU, obradująca w listopadzie 2015 r. w Genewie ${ }^{32}$.

Produkcja i eksploatacja małych satelitów jest tańsza, dlatego też podmioty prywatne podjęły inicjatywy mające na celu ich wystrzelenie. Problem polega jednak na tym, że producenci małych satelitów nie mają dużego doświadczenia, a organy regulacyjne są przyzwyczajone do dużych obiektów. Stąd potrzeba wprowadzenia w prawie krajowym przepisów dotyczących małych satelitów, m.in. ich ubezpieczenia, zasad rejestracji ${ }^{33}$, ochrony środowiska (w tym usuwania pozostałości) ${ }^{34}$. Zasady te powinny być zrównoważone ${ }^{35}$. Mniej elastyczne byłyby kwestie finansowe lub minimalizacja ryzyka $^{36}$. Wiąże się to również z problemem przewidywalności końca okresu eksploatacji satelitów. Duże satelity mogą działać przez kilkanaście lat

${ }^{29}$ J. Pelton, R.S. JAKhu, Small satellites and their regulation, New York: Springer 2014, s. 1.

${ }^{30}$ O.N. John, E. Eguaroje, G. Efron, Judical Admissibility of Satellite data/evidence in Nigerian Courts, $55^{\text {th }}$ Colloquium On Space Law, p. 484.

${ }^{31}$ A. Froehlich, The impact of satellite data used by High International Courts and ITLOS, $55^{\text {th }}$ Coloquiuum On Space, s. 471.

32 A.L. Allison, Accomodating New Commercial Space Applications in the global regulatory framework: a brief look ahead of the Itu'S 2015 World Radiocommunication Conference, $3^{\text {rd }}$ Manfred Lachs International Conference on New Space commercialization and the law, 16-17 March 2015, ICAO.

${ }^{33}$ N. PALKovitz, Small satellites and developments in space law, International Air and Space Law Conference, Gdańsk, Poland 15 November 2013.

${ }^{34}$ I. MARboe, K. TRAUnmUller, Small satellites and small states: new incentives for national space legislation, „Journal of Space Law” 38 (2012), nr 2, s. 318.

${ }^{35}$ S. FreEland, New Space, Small satellites and law: finding a balance between innovation, a changing Space Paradigm and Regulatory Control, $3^{\text {rd }}$ Manfred Lachs International Conference on New Space commercialization and the law, 16-17 March 2015, Montreal, ICAO.

${ }^{36}$ M. Othman, A. Matas, $3^{\text {rd }}$ Manfred Lachs International Conference on New Space commercialization and the law, 16-17 March 2015, Montreal, ICAO. 
(a zmodernizowane technologie powodują, że okres ich eksploatacji będzie w stanie osiągnąc nawet kilkadziesiąt lat), mniejsze - działają tylko przez kilka lat. Nowym wyzwaniem jest również uregulowanie, w przypadku małych satelitów, kwestii transportu towarowego, która jest przedmiotem zainteresowania coraz większej liczby krajów ${ }^{37}$.

Małe satelity są tanie i mogą być budowane nawet przez studentów lub organizacje pozarządowe o niższym budżecie. W ciągu 4 lat (2010-2014) wzrost liczby nano- i mikro-satelitów w skali roku wyniósł $37,2 \%$. W ostatnich latach coraz więcej firm w Ameryce Północnej i w Europie deklaruje swoje zainteresowanie takimi uruchomieniami. Małe satelity mogą stanowić zagrożenie dla istniejących technologii, ponieważ obsługują nowy segment rynku i są tańsze w eksploatacji. Duże istniejące firmy muszą wziąć pod uwagę nowe wyzwania i zagrożenia stwarzane przez nowych graczy i włączyć te innowacje do swoich programów. Istnieje możliwość, że nowe technologie z powodu ich niskich kosztów zagrożą bankom, ubezpieczycielom i funduszom inwestycyjnym ${ }^{38}$. Na razie jednak najwięcej uwagi poświęca się wartościom edukacyjnym i naukowym nanosatelitów, postrzegając je jako przyszłość działalności kosmicznej. Nanosatelity są małe i lekkie, wykorzystywane głównie do celów naukowych i edukacyjnych. Są one zazwyczaj umieszczane na niskiej orbicie Ziemi (mogą być również umieszczone na orbicie średniej).

Satelity te są zazwyczaj wykorzystywane do testowania nowych produktów, zmniejszając ryzyko niepowodzenia misji. Traktuje się je jako „obiekt kosmiczny" odpowiadający przepisom międzynarodowym - w praktyce są one wyłączone z zakresu tego prawa. Nanosatelity będą w przyszłości coraz bardziej popularne (mogą być one również wykorzystywane w misjach komercyjnych). Największym ryzykiem dla nich jest możliwość kolizji, gdyż nie mają one możliwości manewrowania i mogą zostać pozostawione jako śmieci kosmiczne. Operator satelity odbiera dane od niego i może je przesłać na pewien poziom, ale nie może zmienić orbity. Powoduje to pytania o ewentualne kolizje $\mathrm{z}$ innymi obiektami na niższej orbicie, jednak jak dotąd nic takiego się nie wydarzyło. Nanosatelity zwykle palą się, gdy wchodzą w atmosferę ziemską.

\footnotetext{
${ }^{37}$ M. BuzDUGan, Satellite financing through hosted payloads: benefits and challenges, „Air and Space Law" 36 (2011), nr 2, s. 139-160.

${ }^{38}$ L. RAPP, V.D. SANTOS, A. MARTIN, Entering a New Space era; what might be expected from Satellite Miniaturisation?, $3^{\text {rd }}$ Manfred Lachs International Conference on New Space commercialization and the law, 16-17 March 2015, ICAO, Montreal.
} 
Na razie kwestie nanosatelitów w poszczególnych krajach są traktowane różnie, w wielu przypadkach ustawodawstwo krajowe tworzy luki prawne i rozbieżności. Na przykład w prawie holenderskim są one wyłączone z działalności kosmicznej, podczas gdy w prawie belgijskim są objęte prawem krajowym. Zgodnie $\mathrm{z}$ prawem holenderskim licencja nie jest wymagana do wystrzelenia takich satelitów, więc państwo nie jest za nie odpowiedzialne. Kwestia ta jest obecnie przedmiotem dyskusji w parlamencie - podnosi się problem winy za kolizje - trzeba określić, jaki kraj będzie ponosić winę (jeżeli w zderzeniu brał udział obiekt zdolny do manewrowania i ten, który nie jest obiektem kosmicznym). Austria nie wyklucza nanosatelitów (zgodnie z prawem krajowym z 2011 r.) i wymaga od ich właścicieli licencji. Przewiduje również inne przepisy dotyczące ubezpieczenia, jeśli działalność ma charakter komercyjny, a nawet naukowy i edukacyjny ${ }^{39}$. Uzyskanie takiego ubezpieczenia będzie jednak trudne, ponieważ na razie nie ma na rynku takiego taniego ubezpieczenia ${ }^{40}$.

Już w roku 2014 zalecano wykorzystanie małych satelitów, nie tylko do celów pozycjonowania i usuwaniu z orbity używanych satelitów, ale i do rozbrajania toksycznych pocisków rakietowych i systemów zasilania. Kwestie te mogłyby koordynować oenzetowski UNCOPUOS i IADC (Międzyagencyjny Komitet Koordynacji Gruzów Kosmicznych) ${ }^{41}$.

\section{MAŁE SATELITY DZISIAJ}

Świat małych satelitów rozwija się szybko i istnieje możliwość wykorzystania tych urządzeń w celu osiągnięcia znacznego postępu naukowego. W szczególności rosnąca dostępność taniego sprzętu do wystrzeliwania stanowi okazję do zmniejszenia ogólnych kosztów misji naukowych. To z kolei powinno zwiększyć częstotliwość lotów i zachęcić naukowców do proponowania innowacyjnych koncepcji, prowadzących do przełomowych odkryć naukowych. Ponadto nowe technologie i metody komputerowe zmieniają sposób pozyskiwania, zarządzania i przetwarzania danych. Duże zbiory danych, powstałe dzięki małym satelitom, będą wymagały nowych zasad analizy. W sprawozdaniu przygotowanym w roku 2019 przez międzynarodową

\footnotetext{
${ }^{39}$ N. Palkovitz, T.M ZWAan, Orbiting under the radar: nano- satellites, international obligations and national space law, $55^{\text {th }}$ Colloquium on Space Law, s. 578.

40 J.N. Pelton, R.S. JAKHU, Small satellites and their regulation, New York: Springer 2014, s. 1.

${ }^{41}$ Tamże, s. 70.
} 
grupę ekspertów w ramach Komitetu Badań Kosmicznych COSPAR termin „mały satelita” jest nieco arbitralnie zdefiniowany jako statek kosmiczny o górnej granicy masy $\mathrm{w}$ zakresie kilkuset kilogramów ${ }^{42}$. A przecież limit masy jest mniej ważny niż procesy stosowane przy budowie i wystrzeliwaniu danych satelitów ${ }^{43}$. Celem mapy drogowej zawartej w tym sprawozdaniu jest zachęcenie środowiska naukowego, zajmującego się przestrzenią kosmiczną, do stymulowania rozwoju drobnego przemysłu satelitarnego w celu zwiększenia częstotliwości lotów oraz zmiany sposobu, w jaki małe satelity naukowe są budowane i zarządzane. Przedstawiono pięć zaleceń; po jednym dla społeczności naukowej, przemysłu kosmicznego, agencji kosmicznych, decydentów politycznych i wreszcie dla COSPAR ${ }^{44}$.

W powyższym sprawozdaniu przedstawiono szereg danych dotyczących obecnego wykorzystania małych satelitów na świecie. Europejskie działania w tym zakresie były wspierane na różnych poziomach przez programy krajowe, siódmy program ramowy Unii Europejskiej i program kosmiczny „Horyzont 2020” oraz przez ESA, tj. Europejską Agencję Kosmiczną. Małe satelity o masie powyżej $100 \mathrm{~kg}$ wykazały swoją przydatność dla misji naukowych i wnoszą istotny wkład w wiedzę z zakresu nauk o Kosmosie, szczególnie w poddziedzinach heliofizyki, astrofizyki i nauk o Ziemi. W Stanach Zjednoczonych większość małych naukowych satelitów jest wspierana w ramach programu NASA Explorers Program, który umożliwia prowadzenie badań naukowych w dziedzinie astrofizyki i heliofizyki.

W 2017 r. uruchomiono 36 małych satelitów CubeSats w celu zbadania górnej atmosfery $w$ ramach zorganizowanej przez UE konstelacji QB50. Udział w tym programie wzięły: Australia, Stany Zjednoczone, Kanada, Chiny, Tajwan, Korea Południowa, Izrael, Republika Południowej Afryki, Turcja i Ukraina.

Doszło także w tej dziedzinie do współpracy innych podmiotów, tak np. kilka nowych firm buduje rakiety dla małych satelitów (np. Rocket Labs i Virgin Orbit). Wydaje się, że sektor komercyjny już opracowuje nowe spo-

${ }^{42}$ R. vON STEIGER, Small satellites for Space Science (4S), a COSPAR Scientific Roadmap, presentation at Israel, Herzilija COSPAR meeting 4-8 November 2019, "Small satellites for Sustainable Science and Development".

${ }^{43}$ R. Millan, R. von Steiger, M. Ariel i in., Small satellites for space science A COSPAR scientific roadmap, „Advances in Space Research” 64 (2019) 1466-1517, s. 1.

${ }^{44}$ Komitet COSPAR ds. badań przestrzeni kosmicznej - organizacja powołana przez Międzynarodową Radę Związków Naukowych (ICSU) w 1958 r. Zadaniem Komitetu jest promowanie i koordynowanie badań przestrzeni kosmicznej na poziomie międzynarodowym, a w szczególności wymiana i rozpowszechnianie informacji na temat badań przestrzeni kosmicznej. W tym celu Komitet organizuje szereg sympozjów, wydaje publikacje itp. 
soby ich budowy i testowania. Znaczący postęp technologiczny otwiera nowe możliwości dla małych satelitów, które stwarzają możliwości znacznego zwiększenia liczby długich misji międzyplanetarnych. Przewiduje się że w latach 2017-2026 zostanie wystrzelonych 3600, 6200 lub nawet 25000 małych satelitów (o wadze poniżej $500 \mathrm{~kg}$ ). Niepokój budzi jednak nie tylko rosnąca liczba tych obiektów, ale również fakt, że (w zależności od wysokości) pozostaną one w przestrzeni kosmicznej jako odłamki dłużej niż ich okres użytkowania. Wraz ze wzrostem liczby tych statków kosmicznych zwiększa się również prawdopodobieństwo kolizji, zwłaszcza jeśli satelity nadal nie zostaną zaopatrzone w przyrządy do manewrowania i nie będą dokładnie śledzone. Ze względu na dużą prędkość $(\sim 10 \mathrm{~km} / \mathrm{s})$, nawet submilimetrowe odłamki stanowią realne zagrożenie dla lotów kosmicznych. Małe satelity, a zwłaszcza cubesaty, w przestrzeni kosmicznej bliskiej Ziemi są coraz częściej postrzegane jako wielki rezerwuar śmieci kosmicznych.

Autorzy powyższego raportu sformułowali szereg zaleceń - po jednym dla społeczności naukowej, przemysłu kosmicznego, agencji kosmicznych, decydentów politycznych i wreszcie dla COSPAR. W pierwszym z nich stwierdza się, że społeczność naukowa jako całość powinna uznać przydatność małych satelitów i poszukiwać możliwości wykorzystania osiągnięć w przemyśle małych satelitów. Wszystkie gałęzie nauki o Kosmosie mogą potencjalnie skorzystać $\mathrm{z}$ tych mniejszych urządzeń i związanych z tym niższych kosztów. Szczególnie społeczności naukowe z małych krajów mogą odnieść korzyści z inwestowania swoich budżetów w małe satelity.

Drugie zalecenie stanowi, że twórcy satelitów powinni szukać możliwości współpracy z poszczególnymi naukowcami i uniwersytetami, jak również z większymi agencjami rządowymi. Może to obejmować porozumienia dotyczące wymiany danych, wynajmowania powierzchni na komercyjnych statkach kosmicznych na potrzeby instrumentów naukowych itp.

Trzecie zalecenie, skierowane do dużych agencji kosmicznych, zachęca je do współpracy z nauką. Agencje powinny znaleźć nowe sposoby zapewnienia pomocy dla nauki, zastosowań i demonstracji technologicznych, opartych na małych satelitach oraz wykorzystywać dane handlowe lub infrastrukturę handlową do prowadzenia badań naukowych w sposób zachowujący politykę otwartych danych. Wreszcie, agencje kosmiczne powinny współpracować w celu stworzenia długoterminowych planów działania, które nakreślą priorytety przyszłych misji międzynarodowych z udziałem małych satelitów ${ }^{45}$.

${ }^{45}$ A. LUKASZCZYK, Space Technology to the power of hundreds, presentation at the COSPAR meeting, Herzilya 4-8 November 2019; A. FreEmAn, SmallSat Constellations for Earth Science - 
W zaleceniu dla decydentów politycznych stwierdza się, że aby małe satelity naukowe odniosły sukces, środowisko naukowe potrzebuje wsparcia ze strony decydentów politycznych: (1) zapewnienie odpowiedniego dostępu do widma radiowego, możliwości łagodzenia skutków zanieczyszczeń orbitalnych i usuwania ich skutków oraz przystępnych cenowo usług w zakresie wystrzeliwania i innych usług infrastrukturalnych; (2) zapewnienie łatwiejszego zrozumienia i interpretacji wytycznych dotyczących kontroli eksportu oraz ustanowienie równowagi między bezpieczeństwem narodowym a interesami naukowymi; (3) zapewnienie edukacji i wytycznych w zakresie krajowych i międzynarodowych przepisów dotyczących dostępu do widma radiowego, identyfikowalności i unieszkodliwiania małych satelitów po zakończeniu ich eksploatacji.

W ostatnim zaleceniu stwierdza się, że COSPAR powinien ułatwić proces, w ramach którego międzynarodowe zespoły mogą wspólnie określać cele naukowe i zasady dla modułowej, międzynarodowej małej konstelacji satelitarnej. Finansowanie pochodziłoby z poszczególnych uczestniczących państw członkowskich, a nawet od podmiotów prywatnych lub fundacji. Rolą COSPAR jest rola uczciwego pośrednika, koordynującego, a nie finansującego. Wyniki takiego międzynarodowego wysiłku byłyby cenne dla wszystkich uczestników badań kosmicznych. ${ }^{46}$

\section{KOMERCJALIZACJA PRZESTRZENI KOSMICZNEJ}

Nowa era w działalności w Kosmosie od początku tworzyła się głównie w oparciu na decyzjach poszczególnych rządów oraz wyspecjalizowanych agencji i międzynarodowych organizacji ${ }^{47}$. Koncepcja komercjalizacji rozwinęła się również w wyniku prowadzonej przez państwa polityki ograniczania budżetów rządowych na badania i naukę. Prof. Dempsey zwraca uwagę na dynamiczne tempo rozwoju sektora prywatnego w przestrzeni kosmicznej, zwłaszcza w okresie spadku aktywności rządu. Globalne działania rządów

it's about timing, presentation at the COSPAR meeting, Herzilya 4-8 November 2019; S. STATHAM, RainCube: Radar weather Observations from a Sustainable, Small Satellite Platform, presentation at the COSPAR meeting, Herzilya 4-8 November 2019.

${ }^{46}$ C. GABRIEL, P. WiLLMORE, COSPAR Capacity building and small satellites, presentation at the COSPAR meeting, Herzilya 4-8 November 2019; M. MCGRATH, Lessons learned in advancing academic space science programs, presentation at the COSPAR meeting, Herzilya 4-8 November 2019.

47 J.N. PELTON, Regulatory issues for new global aerospace systems, [w:] R.S. JAKHU, K.W. CHENG, Regulation of emerging modes of aerospace transportation, McGill, Montreal: Institute of Air and Space Law 2014, s. 77-100. 
i firm prywatnych w zakresie przestrzeni kosmicznej zwiększyły się w $2013 \mathrm{r}$. do 314 mld USD. W latach 2012-2013 przychody z produktów i usług komercyjnych wzrosły do 7\%, a państwowe spadły ${ }^{48}$.

W programie rządu USA na rok 2010 stwierdzono, że jego zadaniem jest m.in. wspieranie i ułatwianie rozwoju komercyjnego sektora kosmicznego, dzięki czemu USA zostaną światowym liderem w Kosmosie. Jednocześnie zanotowano wzrost liczby osób prywatnych w amerykańskich urzędach i instytucjach zajmujących się realizacją amerykańskiego programu kosmicznego. Ponadto nastąpił wzrost aktywności firm prywatnych m.in. np. Virgin Galactic, Bigelow, Microsoft, Amazon i stagnacja niektórych agencji rządowych.

Rząd USA liczy na bliską współpracę agencji rządowych z doświadczonymi agencjami prywatnymi, których koszty działania są stosunkowo niskie, a wyniki zachęcające. W niedalekiej przyszłości Stany Zjednoczone przewidują m.in. 3 rodzaje misji: transport towarowy i załogowy na Platformę ISS, loty kosmiczne $\mathrm{w}$ przestrzeni suborbitalnej oraz misje rozpoznawcze na Marsa. W przypadku lotów z pasażerami na pokładzie, NASA współpracuje $\mathrm{z}$ trzema amerykańskimi liniami lotniczymi. Obecnie w USA istnieje 8 licencjonowanych portów kosmicznych, ale liczba licencjonowanych portów kosmicznych w USA będzie rosła. Następujące stany są zainteresowane budową nowych portów kosmicznych: Texas, Hawaje i Colorado. Również w innych częściach świata pojawiają się nowe pomysły dotyczące lokalizacji atrakcyjnych portów kosmicznych przyciągających operacje suborbitalne (Curacao, Japonia, Szwecja, Hiszpania, Singapur, Wielka Brytania i Zjednoczone Emiraty Arabskie $)^{49}$. Działalność prywatnych przedsiębiorców stale się rozwija; dotyczy nie tylko pasażerów transportu, ale także satelitów (Virgin Galactic). Mówi się nawet, że istnieje nowa koncepcja turystyki suborbitalnej w przestrzeni kosmicznej ${ }^{50}$. W USA niektórzy przedsiębiorcy i NASA są również zainteresowani transportem wypraw lub budową nowoczesnych teleskopów do obserwacji asteroid.

Działalność komercyjna w zakresie przestrzeni kosmicznej prowadzona jest również w Europie. Działają tu firmy takie jak EADS, Astrium, Swiss

\footnotetext{
${ }^{48}$ P.S. DEMPSEY, National legislation governing commercial space activities, Aerospace symposium ICAO March 2015

${ }^{49}$ G.C. NIELD, A new way to look at things, [w:] R. JAKHU, K.W. CHEN, regulation of emerging modes of aerospace transportation, McGill, Montreal: Institute of Air and Space Law 2014, s. 21.

${ }_{50}$ M.E. DIRKX, High hopes and low estimates: new space's rocky contractual road, JSL 36 (2010), nr 1, s. 55.
} 
Space System, Booster, Reaction Engines. Powstają m.in. projekty balonów, które mogą przewozić turystów na dużych wysokościach.

\section{DZIAŁANIA ZWIĄZANE Z ZASOBAMI KOSMICZNYMI}

Duże zainteresowanie wzbudza także eksploracja gospodarcza Kosmosu; istnieje nawet nowe pojęcie „gospodarka księżycowa”. W 2015 r. Stany Zjednoczone przyjęły projekt Ustawy w zakresie komercyjnego wykorzystania przestrzeni kosmicznej (Commercial Space Launch Competitiveness Act $)^{51}$. Projekt ustawy nakazuje prezydentowi, działającemu za pośrednictwem odpowiednich agencji federalnych, ułatwianie komercyjnych poszukiwań i komercyjnego pozyskiwania zasobów kosmicznych przez obywateli USA.

Luksemburg, który nie jest potęgą kosmiczną, przyjął podobne ustawodawstwo. Rząd luksemburski jest bardzo aktywny, organizując sympozja i konferencje, na które sprowadza ekspertów i przedstawicieli biznesu. Współpracuje także z innymi państwami i organizacjami międzynarodowymi (np. UNOOSA) $)^{52}$ przy różnych inicjatywach i projektach kosmicznych. Stworzył dobre warunki ekonomiczne dla firm z branży kosmicznej i użyteczne ramy prawne dla nich. Powstało Centrum Badań nad Zasobami Kosmicznymi. Powstała też ustawa, otwierająca rynek dla firm zewnętrznych na badania przestrzeni kosmicznej (ustawa z 2017 r. o poszukiwaniu i wykorzystaniu zasobów kosmicznych). Art. 1 ustawy stanowi, że „zasoby kosmiczne mogą być własnością. Poszukiwanie jest dozwolone. Zezwolenia udziela się operatorowi na misję eksploracji i wykorzystania zasobów kosmicznych do celów komercyjnych na pisemny wniosek skierowany do ministrów" (art. 3$)^{53}$.

\footnotetext{
${ }^{51}$ Ustawa z 2015 r. o konkurencyjności komercyjnego uruchomienia przestrzeni kosmicznej, czasami określana jako Spurring Private Aerospace Competitiveness and Entrepreneurship (SPACE) Act of 2015, jest aktualizacją ustawy rządu Stanów Zjednoczonych o komercyjnym wykorzystaniu przestrzeni kosmicznej, uchwaloną w 2015 r. Aktualizacja prawa amerykańskiego wyraźnie zezwala obywatelom i przedsiębiorstwom amerykańskim na „udział w komercyjnych poszukiwaniach i eksploatacji zasobów kosmicznych", w tym wody i minerałów. Prawo to nie obejmuje życia pozaziemskiego, więc wszystko, co żyje, nie może być eksploatowane komercyjnie, https://www.congress. gov/bill/114th-congress/house-bill/2262, Public Law nr: 114-90 (dostęp: 25.11.2015).

${ }^{52}$ During last Luxemburg symposium the agreement between Luxembourgian Ministry of Development and UNOOSA was signed about facilitating the space law or space policy making in line with international law for volunteering states.

${ }^{53} \mathrm{https}$ ///spaceagency.public.lu/en/agency/legalframework/law_space_resources_english_tran slation.hml (dostęp: 23.11.2019).
} 
Podczas ostatniego sympozjum poświęconego działalności w Kosmosie, zorganizowanego przez luksemburską Agencję Kosmiczną (13-14 listopada 2019 r.) haska międzynarodowa grupa robocza ds. zarządzania zasobami kosmicznymi przyjęła dokument „Building Blocks for the Development of an International Framework on Space Resource Activities". Grupa robocza została powołana w celu promowania współpracy międzynarodowej i dialogu z wieloma zainteresowanymi stronami w celu ustalenia sposobów eksploatacji gospodarczej zasobów kosmicznych ${ }^{54}$.

\section{WYZWANIA W ZAKRESIE BEZPIECZEŃSTWA W „NOWEJ ERZE W DZIAŁALNOŚCI W KOSMOSIE” („KONCEPCJA 3 SOS”)}

Nowe działania związane z przestrzenią kosmiczną niosą również pewne wyzwania dla społeczności międzynarodowej. Więcej satelitów, więcej badań i więcej odpadów kosmicznych sprawia, że przestrzeń ta jest zatłoczona i niebezpieczna dla użytkowników. Europejska Służba Działań Zewnętrznych rozpoczyna nowe wysiłki na rzecz promowania potrzeby zrównoważonych operacji kosmicznych. Inicjatywa ta zwana „Bezpieczeństwo, ochrona i zrównoważony rozwój przestrzeni kosmicznej (3SOS)" będzie propagować „etyczne postępowanie” w przestrzeni. Inicjatywa ta jest niezbędna, gdyż niskie orbity ziemskie stają się coraz bardziej zatłoczone satelitami i gruzem. Wszystkie podmioty powinny wspólnie przyłączyć się do tej akcji ${ }^{55}$. Na razie nie przewiduje się obowiązkowych regulacji, jednak konieczna jest współpraca operatorów ${ }^{56}$.

\footnotetext{
${ }^{54} \mathrm{Na}$ początku 2020 r. zostanie udostępniony komentarz na temat rozwoju bloków budynków, zawierający informacje na temat każdego z bloków budynków. Informacje na temat jego publikacji zostaną zamieszczone na stronie internetowej Grupy Roboczej.1, więcej zob. https://www.universite itleiden.nl/en/law/institute-of-public-law/institute-of-air-space-law/the-hague-space-resources-governa nce-working-group (dostęp: 23.11.2019).

${ }^{55}$ C. Claeys, Safety, Security and sustainability of Outer Space activities, presentation at the Luxemburg symposium on New Space 2019, 13-14 November 2019.

56 18. eskadra kontroli przestrzeni powietrznej USA ostrzega przed potencjalnym „połączeniem" satelity Aeolus i Starlink44 Europejskiej Agencji Kosmicznej, dnia 2 września o godzinie 11:02 UTC. Eksperci z Biura Debiutów Kosmicznych ESA obliczają prawdopodobieństwo kolizji. W miarę upływu dni prawdopodobieństwo kolizji wzrasta, a w środę 28 sierpnia zespół dociera do Starlink w celu omówienia opcji. Starlink nie planuje podjęcia działań. Próg ESA do przeprowadzenia manewru unikania to prawdopodobieństwo kolizji większe niż 1 na 10000, które zostanie osiągnięte do czwartku wieczorem. W niedzielę podejmuje się decyzję o wykonaniu manewru. W poniedziałek 2 września, o godz. 10:14, 10:17 i 10:18 UTC, połowa orbity przed
} 
ESA ze swej strony proponuje automatyczną inicjatywę w zakresie szacowania i ograniczania ryzyka jako część swoich działań na rzecz bezpieczeństwa $\mathrm{w}$ przestrzeni kosmicznej. Zapewni to i zademonstruje rodzaje technologii potrzebnych do zautomatyzowania procesu unikania kolizji, co pozwoli na przyspieszenie całego procesu generowanego przez maszyny, skoordynowanych i bezkonfliktowych decyzji manewrowych - co jest niezwykle potrzebne do ochrony niezbędnej infrastruktury kosmicznej w nadchodzących latach.

Trzy koncepcje SOS (przyjęte także przez Międzynarodową Federację Astronautyczną - IAF) skierowane zostały do rządów w oczekiwaniu na ich pomoc $^{57}$. Projekt ten w czerwcu 2019 r. został poparty przez Zgromadzenie Ogólne ONZ ${ }^{58}$.

\section{WNIOSKI}

Nowej erze działalności w Kosmosie, jako modelu działania w przestrzeni kosmicznej, stawia się nowe wyzwania przed: rządami, nowymi uczestnikami rynku kosmicznego oraz prawodawcami. Stały proces komercjalizacji Kosmosu wymaga dostosowania istniejącego prawodawstwa do aktualnych potrzeb i wyzwań. Wyzwania gospodarcze i te związane z bezpieczeństwem, przedstawione $\mathrm{w}$ pracach nad działalnością kosmiczną w „nowej erze działalności w Kosmosie" i związane z nimi ograniczenia i problemy pokazują, jak ważna jest pokojowa współpraca między państwami.

Od samego początku „nowej ery działalności w kosmosie” istniały nierówności w rozwoju gospodarczym i przestrzennym krajów i społeczeństw, co powodowało ich różne możliwości dostępu do Kosmosu. W miarę postępu technicznego i wobec pojawienia się małych satelitów dostęp do przestrzeni kosmicznej jest coraz łatwiejszy i tańszy. Sprzyja to małym krajom, podmiotom prywatnym, instytucjom naukowym, a nawet studentom.

potencjalnym zderzeniem, uruchamia się serię poparzeń silników, pierwszy w historii „manewr unikania kolizji" wykonywany przez ESA w celu ochrony jednego z jej statków kosmicznych przed zderzeniem z satelitą w dużej konstelacji; https://eeas.europa.eu/topics/economic-relations-connectivity-in novation/67538/sos-sos-sos-eu-calls-ethical-conduct-space-avoid-collision-and-orbital-debris_en (dostęp: 23.11.2019), https://www.esa.int/Safety_Security/ESA_spacecraft_dodges_large_constellation (dostęp: 22.11.2019).

${ }^{57}$ C. Claeys, Safety, Security and sustainability, więcej zob. IAF (International Astronautical Congress) and IAC (International Aeronautical Congress) in Washington 21-25 October 2019.

${ }^{58}$ www.unoosa.org (23.11.2019). 
Jednak nowa era kosmiczna wymaga rozwiązania wielu konfliktów interesów, aby zapewnić bezpieczeństwo działań kosmicznych prowadzonych przez państwa, przy jednoczesnym zachowaniu ochrony środowiska kosmicznego (gruzów kosmicznych). Wolna i niezakłócona konkurencja, zgodnie z podstawowymi zasadami działalności państw demokratycznych, powinna być wspierana przez nowe programy i strategie kosmiczne oraz krajowe regulacje tak, aby uczynić tę przestrzeń dostępną dla wszystkich. W tym celu niezbędna jest międzynarodowa współpraca, w miarę możliwości ze wszystkimi państwami niezależnie od ich ustroju. Współpraca ta niekiedy nie jest łatwa, ale innej drogi do uniknięcia konfliktu globalnego nie ma.

\section{BIBLIOGRAFIA}

AlLison Audrey L.: Accomodating New Commercial Space Applications in the global regulatory framework: a brief look ahead of the Itu'S 2015 World Radiocommunication Conference, 3rd Manfred Lachs International Conference on New Space commercialization and the law, 16-17 March 2015, ICAO.

BANASZKIEWICZ Marek: Space projects - conference 28-29 May 2015, Warsaw, seminar by European Centre for Parliamentary Research and Documentation, Economic and Budgetary Affairs - some crucial issues for Parliaments in Europe: fiscal policy towards boosting accountability, social security and technological progress.

BöcKSTIEGEL Karl-Heinz: Introductory remarks, [w:] Research and Invention in outer space. Liability and Intellectual Property Rights, red. Sa'id Mosteshar, Dodrecht: Martinus. Nijhoff Publishers 1995, s. 1-6.

Bostwick Philip D.: Liability of aerospace manufacturers: MacPherson v. Buick Sputters into the space age, „Journal of Space Law” (JSL) 22 (1994), nr 1 i 2, s. 75-96.

BuZDUGAN Maria: Satellite financing through hosted payloads: benefits and challenges, „Air and Space Law" 36 (2011), nr 2, s. 136-160.

CAzenave Anny: Monitoring Sea Level Change from Space, „Space Research Today”, nr 205, sierpień 2019.

Claeys Carine: Safety, Security and sustainability of Outer Space activities, presentation at the Luxemburg symposium on New Space 2019, 13-14 November 2019.

DEMPSEY Paul Steven: National legislation governing commercial space activities, Aerospace symposium ICAO March 2015.

DEMPSEY Paul Steven: The evolution of U.S. Space Policy, „Annals of Air and Space Law” (AASL) 33 (2008), s. 325-343.

DiRKX Marielle E.: High hopes and low estimates: new space's rocky contractual road, „Journal of Space Law" 36 (2010), nr 1, s. 55-86.

Dunk Franz G. von der: "Public Space Law and Private Enterprise - The Fitness of International Space Law Instruments for Private Space Activities", in Legal Framework for Privatising Space Activities, Proceedings of the Project 2001 Workshop on Legal Issues of Privatising Space Activities (1999), 12-39. 
FARAND André: Commercialization of International Space Station Utilization: The European partner's Viewpoint, „Air and Space Law” (ASL) 28 (2003), nr 2, s. 83-88.

FreElAND Steven: New Space, Small satellites and law: finding a balance between innovation, a changing Space Paradigm and Regulatory Control, $3^{\text {rd }}$ Manfred Lachs International Conference on New Space commercialization and the law, 16-17 March 2015, Montreal, ICAO.

FREEMAN Anthony: SmallSat Constellations for Earth Science - it's about timing, presentation at the COSPAR meeting, Herzilya 4-8 November 2019;

FroeHLiCH Annette: The impact of satellite data used by High International Courts and ITLOS, $55^{\text {th }}$ Colloquiuum On Space.

Gaubatz William A.: Comments on Certification Standards for New Reusable Launch Vehicles http://www.spacefuture.com/archive/comments_on_certification_standards_for_new_reusabl e_vehicles.shtml (dostęp: 12.08.2020).

JAKHU Ram: Introduction into the conference 3rd Manfred Lachs International Conference on New Space commercialization and the law, 16-17 March 2015, Montreal, ICAO.

John Olusoi N., EguAroje Ezekiel, EFron Gajere: Judical Admissibility of Satellite data/evidence in Nigerian Courts, $55^{\text {th }}$ Colloquium on Space Law.

KERREST Armel: Launching spacecrafts from the sea and the Outer Space Treat: The Sea Launch Project, „Air and Space Law” 23 (1998), nr 1, s. 16-21.

LEE Ricky J.: The Australian Space Activities Act 1998: building the regulatory capacity for a launch Industry [w:] Proceedings United Nations/International Institute of Air and Space Law Workshop on Capacity Building In Space Law Space Activities 2003.

LEISTER Valnora, FrAZIER Mark C.: The role of national and international law in the regulation of space activities, Proceeding of the forty third colloquium on the law of outer space, International Institute of Space Law of the International Astronautical Federation, 2-6 X 2000, Brazil-UN (United Nations): Rio de Janeiro-New York.

ŁUKASZCZYK Agnieszka: Space Technology to the power of hundreds, presentation at the COSPAR meeting, Herzilya 4-8 November 2019.

Marboe Irmgard, Traunmuller Karin: Small satellites and small states: new incentives for national space legislation, „Journal of Space Law” 38 (2012), nr 2, s. 289-320.

McGrath Melissa: Lessons learned in advancing academic space science programs, presentation at the COSPAR meeting, Herzilya 4-8 November 2019.

MINEIRO Michael: Regulatory uncertainty for non-traditional commercial space activities $3^{\text {rd }}$ Manfred Lachs International Conference on New Space commercialization and the law, 16-17 March 2015, Montreal, ICAO.

MineIRo Michael C.: Law and Regulation Governing U.S. Commercial Spaceports: Licensing, Liability, and Legal Challenges, ,Journal of Air Law and Commerce” 73 (2008), nr 4, s. 759.

Monserrat Filho Jose: Why and how to define ,global public interest, Proceeding of the forty third colloquium on the law of outer space, International Institute of Space Law of the International Astronautical Federation, 2-6 X 2000, Brazil-UN (United Nations): Rio de Janeiro-New York.

Nield George C.: A new way to look at things, [w:] Ram S. JAKhU, Kuan-Wei ChenG, Regulation of emerging modes of aerospace transportation, McGill, Montreal: Institute of Air and Space Law 2014, s. 19-30. 
Nyman-MetCALF Katrin: Activities in space- appropriation or use? Göteborg: Uppsala Universitet, Acta Universitatis Upsaliensis 1999.

Othman Mazlan, Matas Atilla: $3^{\text {rd }}$ Manfred Lachs International Conference on New Space commercialization and the law, 16-17 March 2015, Montreal, ICAO.

PAlKovitz Neta, ZwAAn Tanya M.: Orbiting under the radar: nano- satellites, international obligations and national space law, $55^{\text {th }}$ Colloquium On Space Law.

PALKOvitz Neta: Small satellites and developments in space law; International Air and Space Law Conference, Gdańsk, Poland 15 November 2013

Pelton John N., JAKHU Ram S.: Small satellites and their regulation, New York: Springer 2014.

PELTON John N.: Regulatory issues for new global aerospace systems, [w:] Ram S. JAKHU, KuanWei CHENG, Regulation of emerging modes of aerospace transportation, McGill, Montreal: Institute of Air and Space Law 2014, s. 77-100.

RAPP Lucien, SAntos Victor Dos, Martin Adriana: Entering a New Space era; what might be expected from Satellite Miniaturisation? $3^{\text {rd }}$ Manfred Lachs International Conference on New Space commercialization and the law, 16-17 March 2015, ICAO, Montreal.

RoBINSON George S.: Space jurisdiction and the need for a trans global cybernation: the underlying biological dictates of Humankind dispersal, migration and settlement in near and deep space, „Annals of Air and Space Law” 39 (2014), s. 325.

SAGAR David: Privatization of the intergovernmental satellite organizations, [w:] Le droit de l'espace et la privatisation des activites spatiales, red. Armel Kerrest, Paris: Journée d'étude 2003, s. 43-61.

SALIN Peter A.: Orbites, fréquences et asteroïdes a l'heure de la commercialization des activités spatiales (vers une appropriation graduelle du patrimoine de l'espace?), „Annals of Air and Space Law" (AASL) 26 (2001), s. 179-195.

SKAAR Rolf: Commercialization of space and its evolution, will new ways to share risks and benefits open up a much largare space market, European Space Policy Institute. Report nr 4, maj 2004.

StAтнам Shannon: RainCube: Radar weather Observations from a Sustainable, Small Satellite Platform, presentation at the COSPAR meeting, Herzilya 4-8 November 2019.

STEIGER VON Rudolf: Small satellites for Space Science (4S), a COSPAR Scientific Roadmap, presentation at Israel, Herzilija COSPAR meeting 4-8 November 2019, „Small satellites for Sustainable Science and Development".

StOtLeR Charles W.: International and U.S. national laws affecting commercial space tourism: how ITAR tips the balance struck between international law and the CSLAA (Commercial Space Launch Amendment Act), ,Journal of Space Law” 33 (2007), nr 1, s. 245-298.

TREPCZYNSKI Susan: Benefits of granting immunity to private companies involved in commercial space ventures, „Annals of Air and Space Law” 31 (2006), s. 381-403.

UwE SChröGL Karl: Regulations for future space traffic control and management, [w:] J. Pelton and R.S. Jakhu, Introduction to space safety regulations and standards, Nidjihof: Elsevier 2010, s. 303-309.

VISSEPÓ Varlin J.: Legal aspects of reusable launch vehicles, „Journal of Space Law” 31 (2005), nr 1, s. 165-217.

WASSENBergh Henry: Access of private entities to airspace and outer space, „Annals of Air and Space Law" 24 (1999), s. 311-331. 
WASSENBERGH Henry: The art of regulating international air and space transportation, an exercise in regulatory approaches to analyzing air and space transportation, „Annals of Air and Space Law" (AASL) 23 (1998), s. 201-229.

Willmore Gabriel, VILlmore P.: COSPAR Capacity building and small satellites, presentation at the COSPAR meeting, Herzilya 4-8 November 2019.

\section{NEW SPACE (NOWA ERA DZIAŁALNOŚCI W KOSMOSIE) \\ - PROBLEMY PRAWNE I GOSPODARCZE ORAZ KWESTIE BEZPIECZEŃSTWA}

\section{Streszczenie}

New Space (nowa era działalności w Kosmosie) oznacza ewolucyjny proces od ery komercjalizacji i prywatyzacji, którą charakteryzowały kontrakty rządowe (gdzie rząd działał jako najemca i nabywca sprzętu) do ery komercyjnej, gdzie rząd i firmy prywatne nabywają usługi z sektora prywatnego. Stała komercjalizacja wymaga dostosowania istniejącego prawodawstwa do aktualnych potrzeb i wyzwań. Istnieje ponadto potrzeba wspólnego zrozumienia zasad swobody dostępu do przestrzeni kosmicznej oraz potrzeba jej globalnego rozwoju.

Obowiązki nałożone w art. VI układu kosmicznego (OST) z 1967 r., dotyczące autoryzacji i stałego nadzoru, są w gestii państw. Kwestia związana z jurysdykcją staje się dotkliwa dla podmiotów prywatnych, kiedy ta wolność zostaje transponowana na poziom narodowy i prywatny. Koncepcja odpowiedzialności za działalność niezgodną z zasadami prawa międzynarodowego, w tym działalność podmiotów prywatnych, i odpowiedzialność państwa za szkody wyrządzone przez obiekty kosmiczne, w tym przez prywatnych operatorów, staje się najbardziej fundamentalną kwestią międzynarodowego prawa kosmicznego z perspektywy prywatyzacji działalności kosmicznej.

Państwa są więc zmuszane do podjęcia wewnętrznych działań, do monitorowania i kontroli działalności prywatnej przedsiębiorców. Współdziałanie międzynarodowej i krajowej legislacji jest konieczne w obliczu prywatyzacji działalności kosmicznej. Państwa kontrolują prywatne przedsiębiorstwa, mają mechanizmy legislacyjne potrzebne do ustalenia reżimu licencjonowania i monitoringu oraz system sankcji.

Wyzwania gospodarcze $\mathrm{i}$ te związane $\mathrm{z}$ bezpieczeństwem, przedstawione $\mathrm{w}$ pracach nad działalnością kosmiczną w „,nowej erze działalności w kosmosie” i z nimi związane ograniczenia i problemy pokazują, jak ważna jest pokojowa współpraca między państwami.

Słowa kluczowe: Nowa Era; małe satelity; śmieci kosmiczne; komercjalizacja; wykopaliska kosmiczne; bezpieczeństwo

\section{NEW SPACE - LEGAL AND ECONOMIC PROBLEMS AND SECURITY ISSUES}

\section{Summary}

There is no one definition of the term "New Space". The term is commonly used by those involved in construction spacecraft, as well as in the creation of space law. This term may mean the evolutionary process since the era of commercialization and privatization, which was characterized by government contracts (where the government acted as tenant and purchaser of the equip- 
ment) until the commercial era, where the government and private companies purchase services from the private sector. The era of New Space as a new model of activities in space poses new challenges for: governments, new space market actors as well as lawmakers. Permanent commercialization needs to adapt existing legislation to meet current needs and challenges. There is a need for common understanding freedom of access to space and the need for its global development in the New Space era. The economic and security challenges presented in the work in space activity in New Space and related to with them, the limitations and problems show how important peaceful cooperation between states is.

Keywords: New Era; small satellites; space debris; commercialization; space resources; security 